\title{
RESEARCH
}

Open Access

\section{Treatment adherence amongst drug users attending public and private methadone maintenance clinics in a northern province of Vietnam}

Tuan Anh Le', Giang Hai Ha², Mai Quynh Thi Le', Lien My Hoang Tran¹, Duyen Thanh Thi Pham', Ninh Hai Thi Tran³ ${ }^{3}$ Giang Thu Vu', Long Hoang Nguyen ${ }^{5}$, Hai Quang Pham², Cuong Tat Nguyen ${ }^{2 *}$, Tung Hoang Tran ${ }^{6,7}$, Kiet Tuan Huy Pham ${ }^{8}$, Bach Xuan Tran ${ }^{8,9}$, Carl A. Latkin', Cyrus S. H. Ho ${ }^{10}$ and Roger C. M. Ho $\mathrm{H}^{5,11,12}$

\begin{abstract}
Background: Methadone maintenance treatment (MMT) has been proven to be effective in improving health status and the quality of life of illicit drug users. Due to the quick expand of methadone program, socialization through co-payment service is a critical to the success of it. In Nam Dinh, Vietnam, MMT has been used in public clinics and one private clinic. Such effectiveness of this treatment has been found to depend largely on adherence to treatment. This study aims to explore the compliance rate and its influencing factors among drug users between public and private clinics in Nam Dinh province, Vietnam.
\end{abstract}

Methods: A cross-sectional study was conducted on 395 participants from January to September in 2018 in three MMT clinics in Nam Dinh, Vietnam. We applied the convenience sampling technique to recruit respondents. Data on socioeconomics characteristics, MMT adherence (measured by Visual Analogue Scale - VAS) and level of social/ family support were collected.

Results: $43.3 \%$ of participants reported complete adherence to the MMT program during the time of research. Significant factors affect MMT adherence among illicit drug users including family income, history of drug rejections, concurrence in drug usage, far distance from MMT clinics, and having only peer. Patients in MMT private clinic had higher complete adherence than that of public MMT $(\mathrm{OR}=1.82,95 \% \mathrm{Cl}=1.13 ; 2.94)$. Having contacts with peer drug users associated with a higher rate of incomplete adherence $(\mathrm{OR}=2.83,95 \% \mathrm{Cl}=1.39 ; 5.73)$.

Conclusions: The findings support the establishment of private MMT clinics alongside public ones, while further researches to determine the optimal dose and ways to reduce the impact of peer drug user's influence are encouraged to be conducted.

Keywords: Adherence, Public methadone maintenance clinics, Private methadone maintenance clinics, Vietnam

\footnotetext{
* Correspondence: cuong.ighi@gmail.com

${ }^{2}$ Institute for Global Health Innovations, Duy Tan University, Da Nang 550000,

Vietnam

Full list of author information is available at the end of the article
}

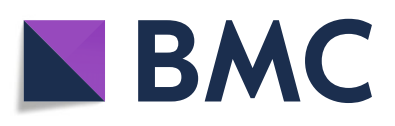

(- The Author(s). 2020 Open Access This article is licensed under a Creative Commons Attribution 4.0 International License, which permits use, sharing, adaptation, distribution and reproduction in any medium or format, as long as you give appropriate credit to the original author(s) and the source, provide a link to the Creative Commons licence, and indicate if changes were made. The images or other third party material in this article are included in the article's Creative Commons licence, unless indicated otherwise in a credit line to the material. If material is not included in the article's Creative Commons licence and your intended use is not permitted by statutory regulation or exceeds the permitted use, you will need to obtain permission directly from the copyright holder. To view a copy of this licence, visit http://creativecommons.org/licenses/by/4.0/. The Creative Commons Public Domain Dedication waiver (http://creativecommons.org/publicdomain/zero/1.0/) applies to the data made available in this article, unless otherwise stated in a credit line to the data. 


\section{Background}

Drug use disorder is considered to be one of the most serious public health problems globally [1]. The number of worldwide death cases caused by drug misuse has been increasing by more than $60 \%$ in the period $2000-$ 2015 [2]. Drug misuse posed a threat to not only personal health but also socioeconomic problems, such as poverty and family breakdown [3]. Vietnam is not an exception, with the number of registered drug illicit users was 222,582 people in 2017 and 31,551 people were arrested involving in drug-related crimes in 2014 [4]. Moreover, injecting drug use caused more than $50 \%$ of all reported cases of Human Immunodeficiency Virus (HIV) [5]. To combat the drug use and reduce the HIV/ AIDS among high-risk behavior community, methadone maintenance treatment (MMT) has been launched since $2008[5,6]$. Several studies showed the benefits of MMT maintenance worldwide: reduced HIV transmission among drug injecting users and criminal activities caused by drug users [7]; helped reducing death rates, morbidity and social illness or being homeless [8-10].

In the Vietnamese context, MMT has been proved to be effective to reduce HIV transmission [11, 12]. The long-term effects of opioids (physical dependence and addiction) are reducing among patients having MMT treatment [13]. MMT increased the quality of life of both drug users and their families [14].

MMT is a long-term therapy and its effectiveness can be achieved with good adherence [15] because poor adherence reduces the positive effect of an intervention, which leads to health worsening and health care cost increasing [16]. Especially in MMT, failure to adherence is a risk factor for overdose causing by the changes of the central nervous system [17]. In China, the medication adherence rate has ranged from $11.8 \%$ at 8 years in Xi'an (14 clinics, 2006-2013) [18] to $26.57 \%$ at 5 years in Yunnan (1 clinic, 2007-2011). In Canada, a 15-year research found a very low rate of adherence to MMT among homeless adults with mental illness [10]. In Vietnam, the level of incomplete MMT adherence was various from the big city (from 8.3 to $17.7 \%$ ) [11] to the mountainous setting (37.7\%) [19].

Several scientific papers have identified the factors associated with MMT medication adherence. They were non-treatment factors such as sociodemographic characteristics (stable job, and monthly income), social support (family, children, and health staff support), and social stigma $[11,19,20]$; treatment-related factors such as ehealth (mobile phone support) or methadone dose [21].

In Western countries, such as Canada, the United States or Europa, MMT is provided mostly by four main providers of MMT, including family physicians, multidisciplinary clinics, private clinics, and prisons [22, 23]. Meanwhile, in China or Vietnam, MMT is applied by public clinics $[24,25]$. However, since 2015, to maintain and ensure the expand of the MMT program, Vietnam government is encouraged to establish private clinical model or socialization methadone treatment. Local provinces are responsible for finance the fees and some part of it is the co-payment from the patients (e.g., incidental supplies) [24].

Nam Dinh is one of the provinces that have the highest number of drug users in the North of Vietnam [26]. By the end of 2016, there were eight MMT clinics in the province, making it the 8th among 61 provinces of Vietnam with the most MMT clinics. Furthermore, Nam Dinh was the first province in Vietnam to establish a private MMT clinic in Vietnam. The Vietnamese government has started to involve the private health sector in providing MMT services as a preparation for the reduction and possible withdrawal of foreign funding that has long allowed the government to provide MMT to patients free-of-charge. There is no difference in the opening hours or payment between private and public MMT clinics and both establishments are under the same government control, including being granted, re-granted or withdraw the operation license for MMT treatment establishment, sending monthly reports to the local provincial agencies [27]. The establishment of private MMT clinics has sparked some debates on how those with drug use disorders, many from a financially disadvantaged background and without permanent jobs, would afford the cost of MMT and related services. Thus, understanding the level of adherence of MMT patients in two clinic models in Nam Dinh as well as the factors associated with adherence would bring valuable insights into the MMT situation in Vietnam and help identify possible areas for improvement. The aim of this study is to explore the medication adherence level among drug users enrolled in MMT clinics in Nam Dinh and determine the factors influencing adherence to treatment.

\section{Methods \\ Study setting and subjects}

A cross-sectional survey was used to collect data in Nam Dinh province from January to September 2018. The study was conducted at 3 outpatient clinics including Giao Thuy district health center (public model), Dai Dong private health facility (private model) and Giao Thuy Center for Social Evils Prevention (public model). The eligibility criteria for selecting MMT clinics were (1) following the guidelines of the Vietnamese Ministry of Health $(\mathrm{MOH})$ in Methadone treatment [28]; (2) providing methadone treatment was at least 12 months.

The convenience sampling technique was used to recruit participants who fulfilled the following criteria: 1) at least 18 years old; 2) receiving Methadone treatment from above clinics; 3) giving consent to participate in 
the study; 4) being able to be communication with the data collection personnel. Participants, who were unable to answer the question during the recruitment process, were excluded from the research. In total, people agreed to participate in the study. According to the regulation of the Vietnam Government, the patients must go to the fixed clinics which they registered in advance. The proportion of patients in three health facilities were as follow: 49.4\% (Dai Dong private health facility), 25.3\% (Giao Thuy district health center) and 25.3\% (Giao Thuy Center for Social Evils Prevention).

\section{Measure and instruments}

Participants were invited to participate in 20-min face-toface interviews. The data collectors were trained well to ensure data is collected timely and accurately. In order avoid social desirability bias, we did not invite local health staff to participate in data collection. We recruited MMT patients when they visited clinics for receiving treatment. The interview was processed in a private room with restricted access to ensure privacy and confidentiality. After introducing the purpose of the study, the advantages and disadvantages when participating in the study, participants were asked whether they want to join the research and the informed consent was given verbally. The participants did not receive any compensation when taking part in the study.

In the pilot survey, there were 20 people participating with various characteristics to examine the acceptability and reliability of the questionnaire. Only slight changes in wording were made to be suitable for a participant's preferences and local culture. We developed a structured medication questionnaire with the following facts:

\section{Socioeconomic characteristics}

The information including gender, age, marital status, education, occupation, monthly income was self-reported by participants.

\section{Adherence to methadone maintenance treatment services We use the 100-point visual analog scale (VAS) to detect patients' adherence. The scores of this scale range from 0 "incompletely adherence" to 100 "completely adher- ence". The information on MMT duration and the num- ber of times that participants missed doses in the last 30 days were also extracted from medical reports.}

\section{Social/family support}

To recognize the back from family and social, we inquired participants about whether they received the support during MMT duration, subjects that they need support the most, the most effective measure implemented to ensure dosage adherence and the kinds of support they feel necessary for complete adherence to MMT.

\section{Statistical analysis}

We used STATA version 14 (Stata Corp. LP, College Station, United States of America) to analyze the data. A Chi-square test and a Mann Whitney test were used for analyzing demographic characteristics and social/family support of MMT clients. We proposed and explored a multivariate logistic regression model to identify factors associated with adherence to MMT service. We used a backward stepwise selection strategy that removed factors that had a p-value of log likelihood ratio test greater than 0.2 . A value of $p<0.05$ was perceived as statistical significance.

\section{Results}

Table 1 shows the demographic and substance use characteristics of participants. Most of the participants (74.7\%) fell in the age range $30-50$ years old and had at least secondary school education (83.3\%). In terms of marital status, the majority of participants were living with partners/spouses (77\%). Risky behaviors of alcohol drinking and smoking were reported in the majority of respondents (53.4 and $81 \%$, respectively). The average family income was 430.5 USD per month. There were significant differences in terms of age and employment status between completely and incompletely adherence groups.

The medication adherence among MMT patients is shown in Table 2. The complete adherence was reported in only $43.3 \%$ of respondents. Regarding missing dose, $90.9 \%$ of the patients reported not ever missed dose within the last 30 days. The median of the number of missed doses in the last 30 days was six (IQR $=2-15,5)$.

Table 3 presents the drug use status and MMT treatment duration of participants. Approximately two-thirds of the respondents had injected drugs (63.8\%). The majority of patients reported no concurrent illicit drug use (94.2\%). Most of the participants (95.4\%) considered their quality of life to be 'better' since enrollment to MMT treatment. The average age of starting to use drug use was 26 years old $(\mathrm{SD}=7.8)$. The mean MMT dose was $69.2 \mathrm{mg}(\mathrm{SD}=37.0)$ and the average MMT treatment duration was 3.3 years $(\mathrm{SD}=2.2)$. There were statistically significant differences in terms of drug injection and concurrent illicit drug use between completely and incompletely adherence groups.

Table 4 reveals the characteristics of social support in MMT treatment. A large portion of participants had received support in MMT treatment from their family (77.7\%) and health workers at MMT facility (41.3\%). These two support providers were also perceived as the most needed sources of support by a high percentage of participants (77.7 and $36.5 \%$, respectively). The majority of patients reportedly considered remembering the treatment schedule by themselves to be the most effective 
Table 1 Demographic and substance use characteristics of participants

\begin{tabular}{|c|c|c|c|c|c|c|c|}
\hline \multirow[t]{2}{*}{ Characteristics } & \multicolumn{2}{|c|}{ Completely adherence } & \multicolumn{2}{|c|}{ Incompletely adherence } & \multicolumn{2}{|l|}{ Total } & \multirow[t]{2}{*}{$\boldsymbol{p}$-value } \\
\hline & $n$ & $\%$ & $n$ & $\%$ & $n$ & $\%$ & \\
\hline \multicolumn{8}{|l|}{ Age group } \\
\hline Under 30 & 10 & 5.9 & 38 & 17.0 & 48 & 12.2 & \multirow[t]{4}{*}{$0.01^{*}$} \\
\hline $30-40$ & 77 & 45.0 & 92 & 41.1 & 169 & 42.8 & \\
\hline $41-50$ & 61 & 35.7 & 65 & 29.0 & 126 & 31.9 & \\
\hline Above 50 & 23 & 13.5 & 29 & 13.0 & 52 & 13.2 & \\
\hline \multicolumn{8}{|l|}{ Education } \\
\hline Less than secondary & 30 & 17.5 & 36 & 16.1 & 66 & 16.7 & \multirow[t]{3}{*}{$0.38^{*}$} \\
\hline Secondary school & 107 & 62.6 & 130 & 58.0 & 237 & 60.0 & \\
\hline More than secondary & 34 & 19.9 & 58 & 25.9 & 92 & 23.3 & \\
\hline \multicolumn{8}{|l|}{ Marital status } \\
\hline Single & 20 & 11.7 & 47 & 21.0 & 67 & 17.0 & \multirow[t]{3}{*}{$0.05^{*}$} \\
\hline Living with partners/ spouses & 141 & 82.5 & 163 & 72.8 & 304 & 77.0 & \\
\hline Divorced/widow & 10 & 5.9 & 14 & 6.3 & 24 & 6.1 & \\
\hline \multicolumn{8}{|l|}{ Employment } \\
\hline Unemployment & 10 & 5.9 & 23 & 10.3 & 33 & 8.4 & \multirow[t]{5}{*}{$0.01^{*}$} \\
\hline Freelancer & 49 & 28.7 & 90 & 40.2 & 139 & 35.2 & \\
\hline Blue collar worker/farmer & 45 & 26.3 & 47 & 21.0 & 92 & 23.3 & \\
\hline Self-employed & 11 & 6.4 & 17 & 7.6 & 28 & 7.1 & \\
\hline Others & 56 & 32.8 & 47 & 21.0 & 103 & 26.1 & \\
\hline \multicolumn{8}{|l|}{ Quintile monthly family income } \\
\hline First & 35 & 20.5 & 45 & 20.1 & 80 & 20.3 & \multirow[t]{5}{*}{$0.65^{*}$} \\
\hline Second & 37 & 21.6 & 45 & 20.1 & 82 & 20.8 & \\
\hline Third & 29 & 17.0 & 52 & 23.2 & 81 & 20.5 & \\
\hline Fourth & 38 & 22.2 & 44 & 19.6 & 82 & 20.8 & \\
\hline Fifth & 32 & 18.7 & 38 & 17.0 & 70 & 17.7 & \\
\hline Alcohol drinking & 88 & 51.5 & 123 & 54.9 & 211 & 53.4 & $0.50^{*}$ \\
\hline \multirow[t]{2}{*}{ Smoking } & 139 & 81.3 & 181 & 80.8 & 320 & 81.0 & $0.90^{*}$ \\
\hline & Mean & SD & Mean & SD & Mean & SD & $p$-value \\
\hline Average family income (USD) & 375.9 & 246.7 & 472.1 & 679.5 & 430.5 & 538.4 & $0.92^{\#}$ \\
\hline
\end{tabular}

*Chi square test, ${ }^{\#}$ Mann-Whiney rank sum test

way for MMT adherence (73.2\%) and no additional type of support needed to improve adherence (75.2\%).

Table 5 demonstrates the health service utilization characteristics of the respondents. Half of the respondents used the public facility (50.6\%). A large portion of respondents considered their distance to MMT facility to be near $(46.1 \%)$ or of reasonable distance. The estimated average distance was $4 \mathrm{~km}(\mathrm{SD}=2.8 \mathrm{~km})$. There were significant differences in terms of MMT model and estimated distance to MMT facility between completely adherence and incompletely adherence group. Regarding satisfaction with daily MMT service, the majority of participants reported being satisfied (78.7\%).

Table 6 describes factors associated with MMT adherence. Participants with monthly family income in the third quintile $(\mathrm{OR}=2.02,95 \% \mathrm{CI}=1.13$; 3.62), had history of drug rejections $(\mathrm{OR}=1.75,95 \% \mathrm{CI}=1.06 ; 2.88)$, engaging in concurrent drug use (Coef $=-27.66$, $95 \% \mathrm{CI}=3.40 ; 224.78)$, receiving only peer support in MMT treatment $(\mathrm{OR}=2.97,95 \% \mathrm{CI}=1.46 ; 6.06)$ and living further away from MMT facility $(\mathrm{OR}=8.82,95 \% \mathrm{CI}=$ 2.09 ; 37.19$)$ were significantly more likely to incompletely adhere to MMT. Being employed and in the fifth (lowest) quintile of average monthly income were found to be positively associated with perceived adherence on the VAS scale. In contrast, participants, who engaged in concurrent illicit drug use, received only peer support in MMT, lived further away from MMT facility, had significantly lower VAS adherence scores. Patients of the public MMT model were found to have a higher chance 
Table 2 Medication adherence among MMT patients

\begin{tabular}{lll}
\hline Characteristics & $\mathrm{n}$ & $\%$ \\
\hline MMT ever missed dose & 36 & 9.1 \\
Yes & 359 & 90.9 \\
No & & \\
MMT adherence & 171 & 43.3 \\
Completely adherence & 224 & 56.7 \\
$\quad$ Incompletely adherence & & \\
Reason for missing dose & 8 & 12.3 \\
Forgetting & 7 & 10.8 \\
Health reasons & 50 & 76.9 \\
Other & Median & IQR \\
& 99 & $90-100$ \\
MMT adherence VAS & 6 & $2-15.5$ \\
Number of missed doses & &
\end{tabular}

of missing dose, while respondents living at a reasonable distance from the MMT facility were less likely to miss a dose.

\section{Discussion}

Although MMT treatment among drug users in Nam Dinh is an important effects to reduce opioid use, the rate of MMT non-adherence in this study was $43.3 \%$. Our research also highlights the positive effects of private clinics compared with public ones and the negative effect of peer-support to MMT treatment. The results of this study could be used to suggest possible adherence policies for MMT patients in Nam Dinh province.

In this study, we found that the level of MMT adherence in Nam Dinh province was $43.3 \%$ over 9 months.
This finding was similar to previous research in Ho Chi Minh anh Hai Phong city, which are two big cities in Vietnam (42.1\%) [11] and lower than that of Tuyen Quang, a mountainous province with the geographical barrier (34.4\%) [21]. Compared with other research, the situation was the same with that in London (42\%) and lower than that in some provinces in China with the adherence rate from 11.8 to $25.8 \%[18,29]$. The rate of MMT adherence is different across countries and regions, thus, there is a need to support drug users not only in pharmaceutical treatment but also in mental health treatment to increase the adherence and ensure MMT retention $[11,30]$.

Multilevel significant predictors of MMT adherence including socio-demographic (age, employment, and income), health care (MMT clinics model, receiving support in MMT service), self-help and other substance use disorder (self-timer, history of drug injection, concurrent illicit drug use), and medication use (MMT dose). Older age was a positive factor to completely adherence, and higher adherence VAS scale. Studies from Western and Eastern countries have also confirmed that older patients had better outcomes and retention in MMT programs meanwhile younger ones are the most likely to drop out substance use disorder treatment [31-34]. This can be explained by the increase in health concern and dissatisfaction with the unhealthy lifestyle among older people [33-35].

Moreover, our finding that distance to MMT clinics was a contributed factor to incomplete adherence. According to $\mathrm{MoH}$ requirement, they have to present at the clinics daily and take it with the presence of health staff, thus, when the MMT facilities are too far from their house, they may have to spend half-day for traveling to the MMT clinics and have no time to work [36].

Table 3 Drug use status and MMT treatment duration of participants

\begin{tabular}{|c|c|c|c|c|c|c|c|}
\hline \multirow[t]{2}{*}{ Characteristics } & \multicolumn{2}{|c|}{ Completely adherence } & \multicolumn{2}{|c|}{ Incompletely adherence } & \multicolumn{2}{|l|}{ Total } & \multirow[t]{2}{*}{$\boldsymbol{p}$-value } \\
\hline & $\mathrm{n}$ & $\%$ & $\mathrm{n}$ & $\%$ & $\mathrm{n}$ & $\%$ & \\
\hline \multicolumn{8}{|l|}{ Ever injected drugs } \\
\hline Yes & 98 & 57.3 & 154 & 68.7 & 252 & 63.8 & $0.02^{*}$ \\
\hline No & 73 & 42.7 & 70 & 31.3 & 143 & 36.2 & \\
\hline \multicolumn{8}{|l|}{ Concurrent illicit drug use } \\
\hline Yes & 1 & 0.6 & 22 & 9.8 & 23 & 5.8 & $<0.01^{*}$ \\
\hline No & 170 & 99.4 & 202 & 90.2 & 372 & 94.2 & \\
\hline \multicolumn{8}{|c|}{ Quality of life since MMT onset } \\
\hline Better & 164 & 95.9 & 213 & 95.1 & 377 & 95.4 & $0.70^{*}$ \\
\hline \multirow[t]{2}{*}{ Unchanged } & 7 & 4.1 & 11 & 4.9 & 18 & 4.6 & \\
\hline & Mean & SD & Mean & SD & Mean & SD & $p$-value \\
\hline Age of onset of drug use & 26.5 & 8.1 & 25.5 & 7.6 & 25.9 & 7.8 & $0.25^{\#}$ \\
\hline MMT duration (year) & 3.2 & 2.2 & 3.3 & 2.2 & 3.3 & 2.2 & $0.38^{\#}$ \\
\hline MMT dose (mg) & 72.9 & 43.7 & 66.4 & 30.7 & 69.2 & 37.0 & $0.29^{\#}$ \\
\hline
\end{tabular}

*Chi square test, ${ }^{*}$ Mann-Whiney rank sum test 
Table 4 Social support in MMT treatment

\begin{tabular}{|c|c|c|c|c|c|c|c|}
\hline \multirow[t]{2}{*}{ Characteristics } & \multicolumn{2}{|c|}{ Completely adherence } & \multicolumn{2}{|c|}{ Incompletely adherence } & \multicolumn{2}{|c|}{ Total } & \multirow[t]{2}{*}{$\boldsymbol{p}$-value } \\
\hline & $n$ & $\%$ & $n$ & $\%$ & $\mathrm{n}$ & $\%$ & \\
\hline \multicolumn{8}{|l|}{ Current support provider } \\
\hline None & 41 & 24.0 & 47 & 21.0 & 88 & 22.3 & $0.48^{*}$ \\
\hline Health workers at MMT facility & 85 & 49.7 & 78 & 34.8 & 163 & 41.3 & $<0.01^{*}$ \\
\hline Other health workers & 4 & 2.3 & 4 & 1.8 & 8 & 2.0 & $0.73^{\zeta}$ \\
\hline Relatives in family & 130 & 76.0 & 177 & 79.0 & 307 & 77.7 & $0.48^{*}$ \\
\hline Peer in MMT & 22 & 12.9 & 45 & 20.1 & 67 & 17.0 & $0.06^{*}$ \\
\hline Neighbors/other acquaintances & 9 & 5.3 & 7 & 3.1 & 16 & 4.1 & $0.29^{*}$ \\
\hline \multicolumn{8}{|l|}{ Perceived needed support provider } \\
\hline None & 35 & 20.5 & 45 & 20.1 & 80 & 20.3 & $0.93^{*}$ \\
\hline Health workers at MMT facility & 77 & 45.0 & 67 & 29.9 & 144 & 36.5 & $<0.01^{*}$ \\
\hline Other health workers & 9 & 5.3 & 7 & 3.1 & 16 & 4.1 & $0.27^{*}$ \\
\hline Relatives in family & 131 & 76.6 & 176 & 78.6 & 307 & 77.7 & $0.64^{*}$ \\
\hline Peer in MMT & 26 & 15.2 & 27 & 12.1 & 53 & 13.4 & $0.36^{*}$ \\
\hline Neighbors/other acquaintances & 10 & 5.9 & 7 & 3.1 & 17 & 4.3 & $0.19^{*}$ \\
\hline \multicolumn{8}{|c|}{ Perceived most needed support provider } \\
\hline None & 46 & 26.9 & 53 & 23.7 & 99 & 25.1 & $0.46^{*}$ \\
\hline Health workers & 125 & 73.1 & 171 & 76.3 & 296 & 74.9 & \\
\hline \multicolumn{8}{|c|}{ Perceived most effective type of support } \\
\hline Self-timer (clock, phone, etc.) & 19 & 11.1 & 39 & 17.4 & 58 & 14.7 & $<0.01^{*}$ \\
\hline Relatives support & 2 & 1.2 & 20 & 8.9 & 22 & 5.6 & \\
\hline Remember by yourself & 144 & 84.2 & 145 & 64.7 & 289 & 73.2 & \\
\hline Other & 6 & 3.5 & 20 & 8.9 & 26 & 6.6 & \\
\hline \multicolumn{8}{|c|}{ Perceived additional type of support to improve MMT adherence } \\
\hline None & 140 & 81.9 & 157 & 70.1 & 297 & 75.2 & $0.01^{*}$ \\
\hline Methods to improve treatment & 3 & 1.8 & 14 & 6.25 & 17 & 4.3 & $0.03^{*}$ \\
\hline Job search guidelines & 10 & 5.9 & 18 & 8.0 & 28 & 7.1 & $0.40^{*}$ \\
\hline Financial support & 26 & 15.2 & 50 & 22.3 & 76 & 19.2 & $0.08^{*}$ \\
\hline
\end{tabular}

*Chi square test, çFisher exact test

The burden of traveling can be a barrier that affects the outcome of the MMT program, especially, in the mountainous and low-income areas of Vietnam where public transport is not covered.

In addition, people, who had a job (worker, or farmer) and higher monthly family income, had better adherence to MMT compared with those who were unemployed and had low income. This can be explained by the copayment for methadone in Vietnam. At public MMT clinics, the current fee that is applied about $0.5 \mathrm{USD} / \mathrm{pa}$ tient/day that about $50 \%$ of the unit cost $[37,38]$. In a recent study, a high level of current patients was willing to pay $32 \mathrm{USD} /$ month. However, this was supported by some demographic factors such as income or education level [12]. Thus, socio-demographic factors should be carefully taken into consideration to maintain MMT after the funding donors are withdrawing from the program, which can ensure the equalities among patients who treated with MMT.

Regarding health care, a previous study in MMT service found that patients without support had lower adherence rate compared with those with support. Our result was in line with other studies, which showed that positive support from MMT providers could increase adherence [39, 40].

In Vietnam, there have been three MMT models: drug rehab center, public clinic, and private clinic. Notably, our study shows that the patients in MMT private clinics had higher complete adherence than the MMT public ones. Both kinds of clinics are under the control of the Vietnam Government and have the same opening hours (during office hours and 7 days a week). For patients in the rehabilitation center, all the fees are covered by the government. With public and private clinics, the government covers 
Table 5 Health service characteristics

\begin{tabular}{|c|c|c|c|c|c|c|c|}
\hline \multirow[t]{2}{*}{ Characteristics } & \multicolumn{2}{|c|}{ Completely adherence } & \multicolumn{2}{|c|}{ Incompletely adherence } & \multicolumn{2}{|l|}{ Total } & \multirow[t]{2}{*}{$\boldsymbol{p}$-value } \\
\hline & $n$ & $\%$ & $n$ & $\%$ & $n$ & $\%$ & \\
\hline \multicolumn{8}{|l|}{ MMT model } \\
\hline Private facility & 96 & 49.2 & 99 & 50.8 & 195 & 100.0 & \multirow[t]{2}{*}{$0.02^{*}$} \\
\hline Public facility & 75 & 37.5 & 125 & 62.5 & 200 & 100.0 & \\
\hline \multicolumn{8}{|c|}{ Estimated distance to MMT facility } \\
\hline Near & 89 & 48.9 & 93 & 51.1 & 182 & 100.0 & \multirow[t]{3}{*}{$0.01^{*}$} \\
\hline Reasonable & 77 & 41.9 & 107 & 58.9 & 184 & 100.0 & \\
\hline Far & 5 & 2.9 & 24 & 10.7 & 29 & 100.0 & \\
\hline \multicolumn{8}{|c|}{ Satisfaction with daily MMT service } \\
\hline Very satisfaction & 8 & 40.0 & 12 & 60.0 & 20 & 100.0 & \multirow[t]{4}{*}{$0.47^{\mathrm{c}}$} \\
\hline Satisfaction & 139 & 44.7 & 172 & 55.3 & 311 & 100.0 & \\
\hline Medium & 24 & 39.3 & 37 & 60.7 & 61 & 100.0 & \\
\hline \multirow[t]{2}{*}{ Dissatisfaction } & 0 & 0.0 & 3 & 100.0 & 3 & 100.0 & \\
\hline & Mean & SD & Mean & SD & Mean & SD & $p$-value \\
\hline Distance to MMT facility (km) & 3.8 & 2.6 & 4.1 & 2.9 & 4.0 & 2.8 & $0.18^{\#}$ \\
\hline MMT service satisfaction & 8.6 & 1.0 & 8.6 & 0.9 & 8.6 & 1.0 & $0.75^{\#}$ \\
\hline
\end{tabular}

${ }^{*}$ Chi square test, ${ }^{C}$ Fisher exact test, ${ }^{\#}$ Mann-Whiney rank sum test

methadone fee and patients are required to copay for other services such as consulting or medical examination [41]. Normally, in Nam Dinh, drug users co-pay under the half US dollar a day for MMT treatment in both private and public MMT clinics [42, 43]. Thus, the higher rate of adherence among patients in MMT private clinic compared with that of public establishments could be explained that the private clinic may be less crowded, so it can offer higher quality service with the shorter waiting time. Consequently, the experience of patients may enhance and encourage them to follow the treatment.

With the withdrawal of international funding donors and restriction of budget, the Vietnam government will face difficulties in covering the full cost of all MMT clinics as well as in providing human resources for treatment. Therefore, the involvement of the private health sector would shoulder the financial and resource burdens, ensuring the availability of MMT services for those in need. On the other hand, subsidization for those of disadvantaged financial background would be necessary. As MMT was a long-lasting treatment, the cost of treatment can be a burden to the patients' families [44, 45]. In essence, it is suggested that the most appropriate model for Vietnam would be the public-private model [46].

In this study, we also found that the adherence among MMT clients was lower in the group having a history of drug injection or still used a drug when being treated with methadone. A higher level of psychological distress [47] and/or the contact with peer drug users, [18], which are considered an unproductive factor. The similarity between peers regarding drug use has been found in several studies
$[48,49]$. Peers have influence on one's individual behavior and that is the outcome of socialization [49]. This result shows the necessity for mental health consultant or treatment for MMT. Moreover, to reduce the negative impact of peers, eHealth intervention should be used to reduce opioid dependence [50].

Furthermore, the proportion of MMT smokers and MMT alcohol dependences, who were MMT nonadherence, was 80.8 and 54.9\%, respectively. MMT patients could suffer smoking-related and alcohol-related diseases [51]. This phenomenon could be explained by the stigmatization when Vietnamese consider opiate absence as a priority [52]. This result suggests that tailored mental counselling for smoking cessation and quit drinking alcohol should be applied in MMT clinics [52].

Our result was along the same lines with some systematic review and randomized control trials research, that found out MMT dose was the main factor in MMT adherence [53-55]. Thus, there is a need to identify a suitable dose, maybe for each patient, to ensure the outcome of MMT [55].

The study is subjected to certain limitations. First, because of the cross-sectional nature that recorded data at one point in time, it would be difficult to reflect the casual association between risk factors and outcomes [56]. Second, the recall bias and social desirability response bias can be caused due to the self-reported data was. Third, the respondents were conveniently recruited may limit generalization to all populations. However, the results of this study still can be used as evidence for identifying risk factors in MMT adherence. In addition, due to 
Table 6 Associated factors with MMT adherence

\begin{tabular}{|c|c|c|c|c|c|c|}
\hline & \multicolumn{2}{|c|}{$\begin{array}{l}\text { Incomplete } \\
\text { adherence }\end{array}$} & \multicolumn{2}{|c|}{ Adherence VAS } & \multicolumn{2}{|c|}{ Ever missed dose } \\
\hline & OR & $95 \% \mathrm{Cl}$ & Coef. & $95 \% \mathrm{Cl}$ & OR & $95 \% \mathrm{Cl}$ \\
\hline Marital status (Living with partners/spouse vs single) & $0.58^{*}$ & $0.33 ; 1.01$ & $3.64^{* *}$ & $0.38 ; 6.90$ & 2.10 & $0.77 ; 5.74$ \\
\hline \multicolumn{7}{|l|}{ Occupation (vs Unemployment) } \\
\hline Self-employed & & & $3.64^{*}$ & $-0.51 ; 7.80$ & & \\
\hline Blue collar worker/farmer & & & $6.41^{* * *}$ & $1.91 ; 10.91$ & & \\
\hline Others & & & $6.33^{* * *}$ & $1.85 ; 10.81$ & & \\
\hline \multicolumn{7}{|l|}{ Quintile monthly family income (vs First) } \\
\hline Third & $2.02^{* *}$ & $1.13 ; 3.62$ & & & & \\
\hline Fifth & & & 2.63 & $-1.16 ; 6.43$ & & \\
\hline Smoke (Yes vs no) & & & & & $4.31^{*}$ & $\begin{array}{l}0.99 ; \\
18.74\end{array}$ \\
\hline History of drug injections (Yes vs no) & $1.75^{* *}$ & $1.06 ; 2.88$ & -2.28 & $-5.34 ; 0.78$ & & \\
\hline Concurrent illicit drug use (Yes vs no) & $27.66^{* * *}$ & $\begin{array}{l}3.40 ; \\
224.78\end{array}$ & $-14.56^{* * *}$ & $\begin{array}{l}-20.15 \\
-8.98\end{array}$ & & \\
\hline MMT dose (mg) & $0.99^{* *}$ & $0.98 ; 1.00$ & $0.04^{*}$ & $-0.01 ; 0.08$ & & \\
\hline \multicolumn{7}{|l|}{ Receiving support in MMT service (Yes vs no) } \\
\hline None & $0.42^{* * *}$ & $0.22 ; 0.78$ & $3.48^{*}$ & $-0.26 ; 7.21$ & & \\
\hline Health workers at MMT facility & $0.28^{* * *}$ & $0.16 ; 0.49$ & $5.28^{* * *}$ & $1.96 ; 8.60$ & & \\
\hline Commune health workers & 0.24 & $0.03 ; 1.73$ & $11.08^{*}$ & $-0.56 ; 22.72$ & & \\
\hline Peer & $2.97^{* * *}$ & $1.46 ; 6.06$ & $-4.00^{*}$ & $-8.02 ; 0.02$ & & \\
\hline $\begin{array}{l}\text { Most effective manner to not miss dose (Remember by yourself vs Self- } \\
\text { timer) }\end{array}$ & $0.39^{* * *}$ & $0.22 ; 0.69$ & & & 0.57 & $0.26 ; 1.23$ \\
\hline MMT model (Public vs Private) & $1.70^{* *}$ & $1.06 ; 2.73$ & $-3.55^{* *}$ & $-6.45 ;-0.64$ & $2.54^{* *}$ & $1.21 ; 5.34$ \\
\hline \multicolumn{7}{|l|}{ Distance to MMT facility (vs Near) } \\
\hline Reasonable & $1.98^{* *}$ & $1.12 ; 3.50$ & $-3.31^{* *}$ & $-6.25 ;-0.37$ & $0.52^{*}$ & $0.24 ; 1.12$ \\
\hline Far & $8.82^{* * *}$ & $2.09 ; 37.19$ & $-7.74 * *$ & $\begin{array}{l}-13.10 \\
-2.39\end{array}$ & & \\
\hline Distance to MMT facility (km) & $0.90^{*}$ & $0.80 ; 1.01$ & & & & \\
\hline
\end{tabular}

*** $p<0.01,{ }^{* *} p<0.05,{ }^{*} p<0.1$

the difference in the background of patients attending public and private clinics, there could be bias when comparing the MMT adherence of two clinic models. In addition, in this study, we employed stepwise selection strategies to produce the reduced model, which might result in bias in parameter estimation and the increased chance of a Type 1 error [57]. Finally, some associated factors such as the support of digital medicine or other psychiatric comorbidity or some services-related factors were not considered in this study. Therefore, more studies are required to meet the knowledge gap for improving the reliability and efficacy of the MMT program in Vietnam.

\section{Conclusions}

In conclusion, the proportion of MMT adherence among drug users in Nam Dinh was similar to that of some countries worldwide. Beside some influencing factors such as socio-demographics, concurrent illicit drug use, and medication use, two factors should be received careful attention were MMT clinic model and the effect of peer drug users to MMT adherence. Further studies should be taken in Vietnam to evaluate the effectiveness of different MMT models to identify the most suitable one as well as to explore in more detail the factors supporting MMT adherence.

\section{Abbreviations}

AIDS: Acquired Immune Deficiency Syndrome; HIV: Human Immunodeficiency Virus; MMT: Methadone maintenance treatment; VAS: Visual analog scale

\section{Acknowledgements}

We would like to express our gratitude to healthcare staff and participants at Dai Dong private health facility, Giao Thuy district health center and Giao Thuy Center for Social Evils Prevention clinics in Nam Dinh province for supporting us perform this study. 


\section{Authors' contributions}

TAL, MQTL, LMHT, DTTP and NHTT conceived and designed of the study. GTV, GHH, LHN, HQP and CTN collected and analyzed the data. TAL, GHH, THT and KTHP wrote the manuscript. TAL, BXT, CAL, CSHH and RCMH reviewed the manuscript. All authors read and approved the final manuscript.

\section{Funding}

This research did not receive any specific grant from funding agencies in the public, commercial, or not-for-profit sectors.

\section{Availability of data and materials}

The datasets used and/or analysed during the current study are available from the corresponding author on reasonable request.

\section{Ethics approval and consent to participate}

The study protocol was reviewed and granted ethics approval by the Institutional Review Board of National Institute of Hygiene and Epidemiology (code: 726/QDVSDTTU).

\section{Consent for publication}

Not applicable.

\section{Competing interests}

The authors declare that they have no competing interests.

\section{Author details \\ ${ }^{1}$ National Institute of Hygiene and Epidemiology, Hanoi 100000, Vietnam. ${ }^{2}$ Institute for Global Health Innovations, Duy Tan University, Da Nang 550000, Vietnam. ${ }^{3}$ National Hospital for Tropical Diseases, Hanoi 100000, Vietnam. ${ }^{4}$ Center of Excellence in Evidence-based Medicine, Nguyen Tat Thanh University, Ho Chi Minh city 700000 , Vietnam. ${ }^{5}$ Center of Excellence in Behavioral Medicine, Nguyen Tat Thanh University, Ho Chi Minh city 700000, Vietnam. ${ }^{6}$ Institute of Orthopaedic and Trauma Surgery, Vietnam - Germany Hospital, Hanoi 100000, Vietnam. 'Department of Lower Limb Surgery, Vietnam - Germany Hospital, Hanoi 100000, Vietnam. ${ }^{8}$ Institute for Preventive Medicine and Public Health, Hanoi Medical University, Hanoi 100000, Vietnam. ${ }^{9}$ Bloomberg School of Public Health, Johns Hopkins University, Baltimore, MD 21205, USA. ${ }^{10}$ Department of Psychological Medicine, National University Hospital, Singapore 119074, Singapore. ${ }^{11}$ Department of Psychological Medicine, Yong Loo Lin School of Medicine, National University of Singapore, Singapore 119228, Singapore. ${ }^{12}$ Institute for Health Innovation and Technology (iHealthtech), National University of Singapore, Singapore 119077, Singapore.}

\section{Received: 3 December 2019 Accepted: 8 April 2020}

Published online: 28 April 2020

\section{References}

1. World Health Organization. Neuroscience of psychoactive substance use and dependence. Geneva: World Health Organization; 2004

2. World Drug Report 2018 (United Nations publication, Sales No. E.18.XI.9). (Available at https://www.unodc.org/wdr2018/prelaunch/WDR18_ Booklet_2_GLOBAL.pdf).

3. Daley DC. Family and social aspects of substance use disorders and treatment. J Food Drug Anal. 2013;21:S73-s76.

4. Department of State to Congress, Bureau of International Narcotics and Law Enforcement Affairs: 2016 International Narcotics Control Strategy Report (INCSR) - Vietnam. 2016.

5. United Nation Office on Drugs and Crime: Vietnam country programme 2012-2017. 2011.

6. Nguyen TT, Nguyen LT, Pham MD, Vu HH, Mulvey KP. Methadone maintenance therapy in Vietnam: an overview and scaling-up plan. Adv Prev Med. 2012;2012:732484.

7. Karki P, Shrestha R, Huedo-Medina TB, Copenhaver M. The impact of methadone maintenance treatment on HIV risk behaviors among high-risk injection drug users: a systematic review. Evid Based Med Public Health. 2016;2.

8. Russolillo A, Moniruzzaman A, Somers JM. Methadone maintenance treatment and mortality in people with criminal convictions: a populationbased retrospective cohort study from Canada. PLoS Med. 2018;15: e1002625.
9. Evans E, Li L, Min J, Huang D, Urada D, Liu L, Hser YI, Nosyk B. Mortality among individuals accessing pharmacological treatment for opioid dependence in California, 2006-10. Addiction. 2015;110:996-1005.

10. Parpouchi M, Moniruzzaman A, Rezansoff SN, Russolillo A, Somers JM. Characteristics of adherence to methadone maintenance treatment over a 15-year period among homeless adults experiencing mental illness. Addict Behav Rep. 2017;6:106-11.

11. Tran BX, Nguyen LH, Tran TT, Latkin CA. Social and structural barriers for adherence to methadone maintenance treatment among Vietnamese opioid dependence patients. PLoS One. 2018;13:e0190941.

12. Tran BX, Nguyen QL, Nguyen LH, Phan HTT, Le HT, Tran TD, Vu TTM, Latkin CA. Expanding co-payment for methadone maintenance services in Vietnam: the importance of addressing health and socioeconomic inequalities. BMC Health Serv Res. 2017;17:480

13. Nguyen TTM, Nguyen LT, Pham MD, Vu HH, Mulvey KP. Methadone maintenance therapy in Vietnam: an overview and scaling-up plan. Adv Prev Med. 2012;2012:732484.

14. Hoang TV, Ha TT, Hoang TM, Nhu NT, Quoc NC, Tam N, Mills S. Impact of a methadone maintenance therapy pilot in Vietnam and its role in a scaledup response. Harm Reduct J. 2015;12:39.

15. Cramer JA. Consequences of intermittent treatment for hypertension: the case for medication compliance and persistence. Am J Manag Care. 1998;4: 1563-8.

16. Jimmy B, Jose J. Patient medication adherence: measures in daily practice. Oman Med J. 2011;26:155-9.

17. Wolff K. Characterization of methadone overdose: clinical considerations and the scientific evidence. Ther Drug Monit. 2002;24:457-70.

18. Zhou K, Li H, Wei X, Li X, Zhuang G. Medication adherence in patients undergoing methadone maintenance treatment in Xi'an, China. J Addict Med. 2017;11:28-33.

19. Nguyen LH, Nguyen HTT, Nguyen HLT, Tran BX, Latkin CA. Adherence to methadone maintenance treatment and associated factors among patients in Vietnamese mountainside areas. Subst Abuse Treat Prev Policy. 2017;12:31.

20. Luo C, Sanger N, Zielinski L, Bhatt M, Shahid H, Shams I, Mouravska N, Luetam S, Hudson J, Thabane L, Samaan Z. Sociodemographic characteristics of patients with children in a methadone maintenance program: a cross-sectional study. Harm Reduction J. 2019;16:13.

21. Nguyen LH, Nguyen LHT, Boggiano VL, Hoang CD, Van Nguyen $H$, Le $H T$, Le HQ, Tran TD, Tran BX, Latkin CA, et al. Quality of life and healthcare service utilization among methadone maintenance patients in a mountainous area of northern Vietnam. Health Qual Life Outcomes. 2017;15:77.

22. Johnson S, MacDonald SF, Cheverie M, Myrick C, Fischer B. Prevalence and trends of non-medical opioid and other drug use histories among federal correctional inmates in methadone maintenance treatment in Canada. Drug Alcohol Depend. 2012;124:172-6.

23. Eiroa-Orosa FJ, Haasen C, Verthein U, Dilg C, Schäfer I, Reimer J. Benzodiazepine use among patients in heroin-assisted vs methadone maintenance treatment: findings of the German randomized controlled trial. Drug Alcohol Depend. 2010;112:226-33.

24. Johns B, Chau LB, Hanh KH, Manh PD, Do HM, Duong AT, Nguyen LH. Association between user fees and dropout from methadone maintenance therapy: results of a cohort study in Vietnam. Health Syst Reform. 2018;4: 101-13.

25. Dai J, Zhao L, Liang Y. Policy implementation of methadone maintenance treatment and HIV infection: evidence from Hubei province, China. Subst Abuse Treat Prev Policy. 2013;8:38.

26. Tran Q, H V. Adherence and associated factors in methadone clinics in Nam Dinh Province, Vietnam. National Institute on Drug Abuse; 2014.

27. Vietnam Government: Government Decree in Providing treatment for opioid addiction with alternative medicine (Nghị định của Chính phủ Quy định về điều trị nghiện các chất dạng thuốc phiện bằng thuốc thay thế). In 96/2012/NE - CP (Minister of Health). 2012.

28. Minister of Health: Quyết định 3509/QĐ-BYT ngày 21/8/2015 ban hành "Hướng dẫn tổ chức thực hiện điều trị nghiện các chất dạng thuốc phiện bằng thuốc Methadone tại cơ sở cấp phát thuốc Methadone [Decision 3509 / QD-BYT dated August 21, 2015 promulgating "Guiding the organization of the treatment of opiate addiction with methadone at the methadone dispensing establishment]. (Minister of Health ed.; 2015.

29. Marienfeld C, Liu P, Wang X, Schottenfeld R, Zhou W, Chawarski MC. Evaluation of an implementation of methadone maintenance treatment in China. Drug Alcohol Depend. 2015;157:60-7. 
30. Parpouchi M, Moniruzzaman A, Rezansoff SN, Russolillo A, Somers JM. The effect of housing first on adherence to methadone maintenance treatment. Int J Drug Policy. 2018;56:73-80.

31. Sarasvita R, Tonkin A, Utomo B, Ali R. Predictive factors for treatment retention in methadone programs in Indonesia. J Subst Abus Treat. 2012;42: 239-46.

32. Yang F, Lin P, Li Y, He Q, Long Q, Fu X, Luo Y. Predictors of retention in community-based methadone maintenance treatment program in Pearl River Delta, China. Harm Reduct J. 2013;10:3.

33. Mertens JR, Weisner CM. Predictors of substance abuse treatment retention among women and men in an HMO. Alcohol Clin Exp Res. 2000;24:1525-33.

34. Saxon AJ, Wells EA, Fleming C, Jackson TR, Calsyn DA. Pre-treatment characteristics, program philosophy and level of ancillary services as predictors of methadone maintenance treatment outcome. Addiction. 1996; 91:1197-209.

35. Stark MJ. Dropping out of substance abuse treatment: a clinically oriented review. Clin Psychol Rev. 1992;12:93-116.

36. Lin CK, Hung CC, Peng CY, Chao E, Lee TS. Factors associated with methadone treatment duration: a cox regression analysis. PLoS One. 2015; 10:e0123687.

37. Tran BX, Ohinmaa A, Duong AT, Nguyen LT, Vu PX, Mills S, Houston S, Jacobs $P$. Cost-effectiveness of integrating methadone maintenance and antiretroviral treatment for HIV-positive drug users in Vietnam's injectiondriven HIV epidemics. Drug Alcohol Depend. 2012;125:260-6.

38. Tran BX, Ohinmaa A, Duong AT, Do NT, Nguyen LT, Mills S, Houston S, Jacobs P. Cost-effectiveness of methadone maintenance treatment for HIVpositive drug users in Vietnam. AIDS Care. 2012;24:283-90.

39. Lin C, Lan CW, Li L, Rou K. Service providers' adherence to methadone maintenance treatment protocol in China. Int J Drug Policy. 2018;56:1-5.

40. Guillou Landreat M, Rozaire C, Guillet JY, Victorri Vigneau C, Le Reste JY, Grall Bronnec M. French experience with buprenorphine : Do physicians follow the guidelines? PLoS One. 2015;10:e0137708.

41. Vietnam Ministry of Finance: Thông tư quy định quản lý và sử dụng nguồn ngân sách nhà nước bảo đảm, hỗ trợ chi phí khám sức khỏe và chi phí điều trị nghiện các chất dạng thuốc phiện bằng thuốc thay thế [Cicular 07/ 2017 Regulation on the management and usage of state budget sources for guarantee and granting health care costs and cost for treating drug addiction with alternative therapy]. (Vietnam Ministry of Finance ed. Vietnam; 2017.

42. Cơ sở điều trị Methadone thuộc Trung tâm Bảo trợ phòng chống TNXH huyện Giao Thủy sau một năm hoạt động [MMT clinic at Giao Thuy Center for Social Evils Prevention - one year of operation] [https://namdinh.gov.vn/ huyengiaothuy/1209/26957/37468/92554/van-hoa-xa-hoi/co-so-dieu-trimethadone-thuoc-trung-tam-bao-tro-phong-chong-tnxh-huyen-giao-thuysau-mot-nam-hoat-dong-.aspx]

43. Nam Dinh province People's Committee: Quyết định về việc ban hành giá một số dịch vụ điều trị nghiện các chất dạng thuốc phiện bằng thuốc thay thế trong các cơ sở điều trị công lập tỉnh Nam Định [Decision on the issuance of several service fees to alternative treatment for drug users at public clinics in Nam Dinh]. (Committee Ps ed. Nam Dinh; 2015.

44. Mannelli P. The burden of caring: drug users \& their families. Indian J Med Res. 2013:137:636-8.

45. Degenhardt L, Charlson F, Ferrari A, Santomauro D, Erskine H, MantillaHerrara A, Whiteford H, Leung J, Naghavi M, Griswold M, et al. The global burden of disease attributable to alcohol and drug use in 195 countries and territories, 1990-2016: a systematic analysis for the Global Burden of Disease Study 2016. Lancet Psychiatry. 2018;5:987-1012.

46. Gholamzadeh Nikjoo R, Jabbari Beyrami H, Jannati A, Asghari Jaafarabadi M. Prioritizing public- private partnership models for public hospitals of Iran based on performance indicators. Health Promot Perspect. 2012;2:251-64.

47. Tran BX, Boggiano VL, Thi Nguyen HL, Nguyen LH, Nguyen HV, Hoang CD, Le HT, Tran TD, Le HQ, Latkin CA, et al. Concurrent drug use among methadone maintenance patients in mountainous areas in northern Vietnam. BMJ Open. 2018;8:e015875.

48. Andrews JA, Tildesley E, Hops H, Li F. The influence of peers on young adult substance use. Health Psychol. 2002;21:349.

49. Dishion TJ, Owen LD. A longitudinal analysis of friendships and substance use: bidirectional influence from adolescence to adulthood; 2009.

50. Blankers M, Mujcic A. E-health and m-health: using new technologies to respond to drug problems; 2017.
51. Do HP, Nguyen LH, Nguyen NPT, Ngo C, Nguyen HLT, Le GT, Nguyen LK, Nguyen CT, Tran BX, Le HT. Factors associated with nicotine dependence during methadone maintenance treatment: findings from a multisite survey in Vietnam. BMJ Open. 2017;7:e015889.

52. Tran BX, Nguyen LH, Do HP, Nguyen NPT, Phan HTT, Dunne M, Latkin C. Motivation for smoking cessation among drug-using smokers under methadone maintenance treatment in Vietnam. Harm Reduct J. 2015;12:50.

53. Amato L, Davoli M, Perucci CA, Ferri M, Faggiano F, Mattick RP. An overview of systematic reviews of the effectiveness of opiate maintenance therapies: available evidence to inform clinical practice and research. J Subst Abus Treat. 2005;28:321-9.

54. Strain EC, Bigelow GE, Liebson IA, Stitzer ML. Moderate- vs high-dose methadone in the treatment of opioid dependence: a randomized trial. Jama. 1999;281:1000-5.

55. Bao YP, Liu ZM, Epstein DH, Du C, Shi J, Lu L. A meta-analysis of retention in methadone maintenance by dose and dosing strategy. Am J Drug Alcohol Abuse. 2009;35:28-33.

56. Sedgwick P. Cross sectional studies: advantages and disadvantages. BMJ 2014;348:g2276.

57. Whittingham MJ, Stephens PA, Bradbury RB, Freckleton RP. Why do we still use stepwise modelling in ecology and behaviour? J Anim Ecol. 2006;75: $1182-9$

\section{Publisher's Note}

Springer Nature remains neutral with regard to jurisdictional claims in published maps and institutional affiliations.
Ready to submit your research? Choose BMC and benefit from:

- fast, convenient online submission

- thorough peer review by experienced researchers in your field

- rapid publication on acceptance

- support for research data, including large and complex data types

- gold Open Access which fosters wider collaboration and increased citations

- maximum visibility for your research: over $100 \mathrm{M}$ website views per year

At BMC, research is always in progress.

Learn more biomedcentral.com/submissions 